Available online at https://jurnal.iainponorogo.ac.id/index.php/eltall

\title{
THE CORRELATION BETWEEN STUDENTS' INTERNET ACTIVITY FREQUENCY AND THEIR VOCABULARY SIZE AT IAIN BUKITTINGGI
}

\author{
M. Rizki Ramadhan \\ Syahrul \\ Institut Agama Islam Negeri Bukittinggi \\ rizki97ramadhan@gmail.com
}

\begin{abstract}
The design of this research was correlational research. This research aimed to find out the correlation between students' internet activity frequency and their vocabulary size. In this research, the researcher found some problems, such as some students frequently used the internet. However, their vocabulary was still limited, and some students rarely used the internet and had much vocabulary. The researcher used quantitative research. The population in this research was 108 students that were the total of the students in the seventh semester in IAIN Bukittinggi. The researcher took 30\% of the population as a sample of this research which was 33 students. The researcher collected the data used questioners and tests. Based on the finding, there was a significant correlation between students' internet activities frequency and their vocabulary size that used SPSS 20. First, It had sig values is smaller than alpha $(0,000001<0,05)$ or $r$-measured was bigger than r-table $0,730>$ 0,3440 . Second, there was a positive correlation between both variables $(+0.730)$. Third, the magnitude of the correlation was high, with a score between 0.71- 0.90. The result showed that there is a correlation between student's internet activity frequency and their vocabulary size.
\end{abstract}

Keywords: Correlation, Internet Activity Frequency, Vocabulary Size

\section{INTRODUCTION}

In this pandemic COVID-19, people use internet in all of the activities in order to limit the face to face interaction. In education, internet really helps teacher and student in learning process to gain the purpose of learning. In this pandemic internet is very importance in learning process, because students just stay at home and do online school at home by used 
Available online at https://jurnal.iainponorogo.ac.id/index.php/eltall

internet. Government said all of people should keep social distancing and physical distancing. In social distancing and physical distancing everyone need internet to communicate with other anyone. It really enhances everyone social life. In internet there was a lot English vocabulary. Vocabulary still becomes an important part in determining the success of learning both first and second language, because vocabulary was one of component for increase someone language skill. Internet ability is captured by someone when she or he can combine technology knowledge and information. In brief, in order to make students got material on the internet students need vocabulary. That why internet activity need vocabulary to increase students skill.

According to Kouvuniemi (2012), the Internet is a vast environment in which language is used in many ways, sometimes even in the form of its own special slang, 'online language'. Most of the content in the Internet is in written form, and majority of it is English. ${ }^{1}$ It means that, English vocabulary become the most needed language to learn because almost all of the contents in the internet using English vocabulary. Weganofa and Lutviana (2018) stated that vocabulary size is the amount of the students' vocabulary. Based on the preliminary research in IAIN Bukittinggi, the researcher found several problems. First, there some students who used internet frequently but their vocabulary was still limited. The students found any vocabulary which didn't their meaning, but the students reluctant to open their dictionary, as the result it will difficult to understand the text in internet. Second, there some students who rarely used internet and them had much vocabulary.

\section{METHODS}

The researcher used the quantitative research. According to Sugiono (2009), a research is called as quantitative because of the data of the research uses numeric and using statistical analysis. The design of this research was correlational research. The research aims to find out correlation between students' internet activity frequency and vocabulary size. The population of this research was the fifth semester students at IAIN Bukittinggi. 
BL'TALL (ENGLISH IANGUAGE 'TIACHING, APPLIED LINGUIS'ICS

Available online at https://jurnal.iainponorogo.ac.id/index.php/eltall

Table 1.1 The Population

\begin{tabular}{|c|c|c|}
\hline $\begin{array}{c}\text { N } \\
\text { o }\end{array}$ & $\begin{array}{c}\text { Clas } \\
\text { S }\end{array}$ & $\begin{array}{c}\text { Tota } \\
1\end{array}$ \\
\hline 1 & A & 33 \\
\hline 2 & B & 37 \\
\hline 3 & C & 38 \\
\hline & $\begin{array}{c}\text { Tota } \\
\text { l }\end{array}$ & 108 \\
\hline
\end{tabular}

The population of this research was 108 students which were the total of the students in the fifth semester in IAIN Bukittinggi. The researcher used accidental sampling. Researcher took $30 \%$ from population as sample of this research which was 33 students. Researcher used this technique because all class is distributed equally. The researcher collected the data used questioners and test.

\section{FINDINGS}

\section{Description of the Data}

Data of Questionnaire and Test

Suharsimi (2015) stated that the questionnaire was scored in range 1 to 5 . The questionnaire was divided into the positive statements and the negative statements. It can be found in the table below:

Table 1.1 Likers Scale

\begin{tabular}{|l|c|c|}
\hline Alternate Options & Positive & Negative \\
\hline Very Agree & 5 & 1 \\
\hline Agree & 4 & 2 \\
\hline Less Agree & 3 & 3 \\
\hline Disagree & 2 & 4 \\
\hline Very Disagree & 1 & 5 \\
\hline
\end{tabular}

Furthermore, The researcher used test to find out the students vocabulary size. The test was adopted from Paul Nation Vocabulary Level Test. The test that will be used to test of vocabulary size is Vocabulary level test.

In summarize, the questionnaire was about the students' internet activity frequency $(X)$ and the test was about vocabulary size $(Y)$. The data from the questionnaire and test were administrated through the Google form which 
BL'TALL (ENGLISH IANGUAGE 'TIACHING, APPLIED LINGUIS'IICS

ANI) II'TIRA'TURE)

Vol. 2 No. 2, 2021

Available online at https://jurnal.iainponorogo.ac.id/index.php/eltall

has been converted to excel file format. The descriptive score of the students' response toward the questionnaire and test can be viewed on the following table:

Table 1.2 Descriptive of Students' Response from the Questionnaire and Test

\begin{tabular}{|l|r|r|r|r|r|}
\hline \multicolumn{1}{|c|}{ Variables } & $\mathrm{N}$ & \multicolumn{1}{|c|}{$\begin{array}{l}\text { Minimu } \\
\mathrm{m}\end{array}$} & $\begin{array}{r}\text { Maximu } \\
\mathrm{m}\end{array}$ & Mean & $\begin{array}{c}\text { Std. } \\
\text { Deviati } \\
\text { on }\end{array}$ \\
\hline Vocabulary Size & 33 & 2,00 & 29,00 & 13,9394 & 7,20217 \\
\hline $\begin{array}{l}\text { Internet } \\
\text { Frequency } \\
\text { Activity }\end{array}$ & 33 & 53,01 & 110,05 & 82,7336 & 14,80262 \\
\hline
\end{tabular}

Based on the table 1.2, there were 33 students who responded to the questionnaire and test. The table questionnaire used likert scale which has alternate options: always, often, sometime, seldom, and never. er. The likert scale was considered as the ordinal type data. In other hand, the test was interval type data. In order to be able to find out the correlation between those two variables, the questionnaire result needed to be converted into interval type data. This was done by using MSI add-ins in Microsoft excel. For the questionnaire of internet frequency activity, The highest score was 110,05 the minimum score was 53,01, the standard deviation was 14,803 , and the mean score was 82.73. For the test, the highest score was 29 points, the lowest score was 2 points, the standard deviation was 7,202, and the mean score was 13.94 .

\section{Prerequisite of Data Analysis}

Before doing the testing the correlation between both variables, there were 3 prerequisite of data analysis. They are: making sure both of the data is interval type data, the data is distributed normally, and the data is linear.

\section{a. Test the normality of the data}

The normality of the data was done in SPSS 20 application. It was done to find out whether the data distributed normally or not. The result of the normality test can be viewed on the table below: 
ILIALL (ENGLISH IANGUAGE 'TEACHING, APPIIED LINGUIS'IICS

ANI) LI'TIRA'TURE)

Vol. 2 No. 2, 2021

Available online at https://jurnal.iainponorogo.ac.id/index.php/eltall

Table 1.3 Normality of the Data

\begin{tabular}{|c|c|c|c|}
\hline & \multicolumn{3}{|c|}{ Shapiro-Wilk } \\
\hline & Statistic & Df & Sig. \\
\hline Vocabulary & ,936 & 33 & ,052 \\
\hline $\begin{array}{l}\text { Internet Activities } \\
\text { frequency }\end{array}$ & 961 & 33 & 277 \\
\hline
\end{tabular}

Based on the table 1.3, the sig value of both variables is 0.052 and 0.277 , while the alpha is 0.05 . In other word, the sig values of both variables are bigger than the alpha which means both of the data was distributed normally.

\section{b. Test the linearity of the data}

Linearity test is intended to determine the pattern of relationships between each independent variable with the dependent variable whether formed the data linear or not. It was done by using SPSS 20. It is used for testing the linear relationship between the independent variable $(X)$ and the dependent variable $(\mathrm{Y})$.

Table 1.4 Linearity of the Data

\begin{tabular}{|c|c|c|c|c|c|c|}
\hline \multicolumn{2}{|c|}{} & $\begin{array}{c}\text { Sum of } \\
\text { Squares }\end{array}$ & Df & $\begin{array}{c}\text { Mea } \\
n \\
\text { Squa } \\
\text { re }\end{array}$ & F & Si \\
g.
\end{tabular}


BL'TALL (ENGLISH IANGUAGE 'TIACHING, APPLIED LINGUIS'ICS

ANI) II'TIRA'TURE)

Vol. 2 No. 2, 2021

Available online at https://jurnal.iainponorogo.ac.id/index.php/eltall

The table 1. showed that significant value of the significant values is 0.063 which is bigger than the alpha $(0.05)$. That means his data is linear.

\section{c. Test the homogeneity of the data}

The purpose of homogeneity test is to know whether the population is the homogeneous or not, so the researcher use the F test. The homogeneity test by using $\mathrm{F}$ test.

Table 1.5 Homogeneity of the Data

\begin{tabular}{|l|c|c|c|}
\hline \multicolumn{2}{|c|}{} & \multicolumn{2}{|c|}{$\begin{array}{c}\text { Levene's Test for Equality of } \\
\text { Variances }\end{array}$} \\
\cline { 3 - 4 } \multicolumn{2}{c|}{} & F & Sig. \\
\hline \multirow{3}{*}{ Score } & $\begin{array}{c}\text { Equal variances } \\
\text { assumed }\end{array}$ & 17,682 &, 083 \\
\cline { 2 - 4 } & $\begin{array}{c}\text { Equal variances } \\
\text { not assumed }\end{array}$ & & \\
\hline
\end{tabular}

Based on the table 1.5 it was found that the sig value is 0.083 and the alpha is 0.05 . This means that $0.083>0.05$ in other word the data is homogenous.

\section{Hypothesis testing}

Correlation between Internet Activities frequency and Vocabulary Size The correlation was done using SPSS 20. It was done especially by Pearson Correlation option in the application. The result of Pearson correlation can be viewed on the table below:

Table 1.6 Correlation of Internet Activities frequency and Vocabulary Size

\begin{tabular}{|c|c|c|c|}
\hline & & $\begin{array}{l}\text { Internet } \\
\text { Activities } \\
\text { Frequency }\end{array}$ & Vocabulary \\
\hline \multirow{3}{*}{$\begin{array}{l}\text { Internet } \\
\text { Activities } \\
\text { frequency }\end{array}$} & $\begin{array}{l}\text { Pearson } \\
\text { Correlation }\end{array}$ & 1 &, $730^{* *}$ \\
\hline & Sig. (2-tailed) & & ,000001 \\
\hline & $\mathrm{N}$ & 33 & 33 \\
\hline
\end{tabular}


ILITALL (ENGLISH IANGUAGE 'TEACHING, APPLIED LINGUIS'IICS

ANI) II'TIRA'TURE)

Vol. 2 No. 2, 2021

Available online at https://jurnal.iainponorogo.ac.id/index.php/eltall

\begin{tabular}{|l|l|c|c|}
\hline \multirow{4}{*}{ Vocabulary } & $\begin{array}{l}\text { Pearson } \\
\text { Correlation }\end{array}$ &, $730^{* *}$ & 1 \\
\cline { 2 - 4 } & Sig. (2-tailed) &, 000001 & \\
\cline { 2 - 4 } & $\mathrm{N}$ & 33 & 33 \\
\hline
\end{tabular}

Based on the table 1.6 that the sig value is 0,000001 . This means that the sig value is smaller than the alpha of the research which is 0,05 . In other word, there was significant correlation between internet activities frequency and vocabulary size. In addition, another way to find out the correlation was to compare the r-measured with the r-table. Based on the table above, the r-measured was 0,730 meanwhile the r-table for $\mathrm{N}=33$ $(\mathrm{df}=31)$ is 0,3440 . Since 0.730 is bigger than 0,3440 this means that there was significance correlation between internet frequency activity and vocabulary size.

The Magnitude of the Correlation between Internet Activities frequency and Vocabulary Size

Table 1.7 Index Correlation Interpretation

\begin{tabular}{|l|l|}
\hline Index & \multicolumn{1}{c|}{$\begin{array}{c}\text { Interpreta } \\
\text { tion }\end{array}$} \\
\hline $0.00-0.20$ & $\begin{array}{l}\text { Very Low correlation. It is ignored or } \\
\text { considered not correlate }\end{array}$ \\
\hline $0.21-0.40$ & Low correlation \\
\hline $0.41-0.70$ & Moderate correlation \\
\hline $\mathbf{0 . 7 1 - 0 . 9 0}$ & High correlation \\
\hline $0.91-1.00$ & Very High correlation \\
\hline
\end{tabular}

Based on the table above, it was known that the correlation was on the 0.71-0.90. This means, the magnitude of the correlation was high. In other word, there was high correlation between internet frequency activities with the students' vocabulary size.

\section{DISCUSSION}

This research supported the theory from Momani (2018) stated that there is a strong positive correlation between students' Internet exposure and their scores on the vocabulary. His finding assured the positive relationship between the Internet exposure frequency and vocabulary learning in EFL context. That is to say the more exposure to the Internet, the more vocabulary EFL students learn. Based on the finding, the research had questions were answered. First, there was significant correlation between internet activities frequency and vocabulary size since sig values is smaller 
Available online at https://jurnal.iainponorogo.ac.id/index.php/eltall

than alpha $(0,000001<0,05)$ or $r$ - measured was bigger than r-table $(0,730>0,3440)$. This means that the students' internet frequency activity could affect their vocabulary size. Second, there was positive correlation between both variables $(+0.730)$. In other word, the more students have activity in the internet the better their vocabulary size. Third, the magnitude of the correlation was high (between $0.71-0.90$ ). that means that there was high correlation between internet frequency activities with the students' vocabulary size. It can be concluded that Ha is accepted since there was significant correlation between internet activities frequency and vocabulary size.

\section{CONCLUSION}

Based on the finding of the research, there were several conclusions. First, there was significant correlation between internet activities frequency and vocabulary size. This means that the students' internet frequency activity could affect their vocabulary size. Second, there was positive correlation between both variables. In other word, the more students have activity in the internet the better their vocabulary size. Third, the magnitude of the correlation was high. This means that there was high correlation between internet frequency activities with the students' vocabulary size. It can be concluded that $\mathrm{Ha}$ is accepted since there was correlation between internet frequency activity and students' vocabulary size. This means the more students use internet the more they are exposed to the English language since the Internet use English in majority, so that the students' vocabulary size would improve.

\section{REFERENCES}

Dogruer, Nazan Ipek Menevis, (2011). Ramadan eyyam, the use of the internet for educational purposes. North Cyprus: Eastern Mediteranian University.

Koivuniemi, Milla. (2012). Learning English vocabulary using the internet: a quantitative study of a group of first-year upper secondary students. Jyväskylä: University of Jyväskylä.

Laufer, B. \& Ravenhorst-Kalovski, G. C. (2010). Lexical threshold revisited: Lexical text coverage, learners' vocabulary size and reading comprehension. Reading in a Foreign Language.

Lee, Louis Leung Paul Multiple. (2004). Determinants of life quality: the roles of internet activities, use of new nedia, social support, and leisure activities. Hong Kong: The Chinese University of Hong Kong. 
ILIALL (ENGLISH IANGUAGE 'TEACHING, APPIIED LINGUIS'IICS

ANI) II'TIRA'TURE)

Vol. 2 No. 2, 2021

Available online at https://jurnal.iainponorogo.ac.id/index.php/eltall

M. Kumar Agarwa. (2010). Internet-based language learning and teaching. Latvia: Riga Technical University.

Momani, Mowaffaq Mohammad. (2015). The relationship between internet exposure and EFL students' vocabulary retention at tabuk university. Saudi Arabia: Tabuk University.

Montgomery, Judy K. (2007). The bridge of vocabulary: evidence based activities for academic success. United States: NCS Pearson Inc.

Sudartini, Siti. (2010). Internet and English language teaching. Yogyakarta: UNY.

Sudiran \& Eni Prasetiyowati. (2014). The implementation of media in teaching English for young learners (EYL). Celtic Journal

Syawal, Patahuddin, \& Nasrullah. (2017). The effect of internet on English learner behavior. Parepare: UMP.

Wan Lin Tan, Angelina. (2017). Relationship between Vocabulary Size and Reading Comprehension Levels of Malaysian Tertiary Students. (Malaysia: Tunku Abdul Rahman University College

Weganofa, Riza and Rizky Lutviana. (2018). Correlation between internet and passive vocabulary size.

Zhong, Yunsheng. 2008. A study of autonomy English learning on the internet. Qinzhou: Qinzhou Unviersity. 